\title{
English as a Foreign Language Lesson Plans During Covid-19 Pandemic in The Senior High School
}

\section{Jayantari, N. L. P.E ${ }^{1}$, Agustini, D.A.E ${ }^{2}$ (D)}

, 2 Ganesha University of Education, Bali, Indonesia

\section{A R T I C L E I N F O}

Article history:

Received February 23, 2021

Revised February 24, 2021

Accepted April 17, 2021

Available online May 25, 2021

\section{Kata Kunci:}

Rencana Pelajaran, Kesulitan

Guru, Kesulitan Siswa

Keywords:

Lesson Plan, Teacher's

Difficulties, Students' Difficulties

DOI:

http://dx.doi.org/10.23887/jpbi.v9 i1.32572

\begin{abstract}
A B S T RA K
Guru kesulitan guru dalam menyusun RPP yang disesuaikan dengan pembelajaran online. Hal ini mengakibatkan siswa mengalami kesulitan dalam mempelajari Bahasa Inggris sebagai bahasa asing (EFL) melalui Google Classroom selama pandemi Covid-19. Tujuan penelitian ini yaitu untuk menganalisis kemampuan dan kesulitan guru dalam menyusun RPP dan kesulitan siswa dalam pembelajaran bahasa Inggris sebagai bahasa asing (EFL) melalui Google Classroom selama pandemi Covid-19. Desain yang digunakan dalam penelitian ini adalah desain Embedded Mix Method. Teknik yang digunakan untuk mengumpulkan data yaitu kuesioner. Instrument yang digunakan untuk mengumpulkan data yaitu angket. Populasi penelitian ini berjumlah 10 guru dan 55 siswa. Kemampuan guru dalam menyusun RPP untuk EFL melalui Google Classroom diukur dan dideskripsikan secara kuantitatif. Sedangkan kesulitan guru dan siswa dideskripsikan dan dianalisis secara kualitatif. Hasil penelitian yaitu kemampuan guru dalam menyusun RPP EFL melalui Google Classroom yaitu 67,50. Dapat disimpulkan bahwa guru EFL kurang mampu dalam memilih prosedur atau langkah pembelajaran, memilih media pembelajaran dam melakukan evaluasi pembelajaran. Siswa juga mengalami kesulitan dalam mempelajari EFL melalui Google Classroom.
\end{abstract}

\section{A B S T R A C T}

Teachers have difficulties in preparing lesson plans that are adapted to online learning. This has resulted in students having difficulty learning English as a foreign language (EFL) through Google Classroom during the Covid-19 pandemic. The purpose of this study was to analyze the abilities and difficulties of teachers in preparing lesson plans and the difficulties of students in learning English as a foreign language (EFL) through Google Classroom during the Covid-19 pandemic. The design used in this research is the Embedded Mix Method design. The technique used to collect data is a questionnaire. The instrument used to collect data is a questionnaire. The population of this study found 10 teachers and 55 students. The ability of teachers to prepare lesson plans for EFL through Google Classroom is measured and described quantitatively. Meanwhile, the difficulties of teachers and students were described and analyzed qualitatively. The study results are the teacher's ability to prepare EFL lesson plans through Google Classroom, which is 67.50. It can be said that EFL teachers are less able to choose learning procedures or steps, choose learning media and evaluate learning. Students also have difficulty learning EFL through Google Classroom.

This is an open-access article under the CC BY-SA license. Copyright (C) 2021 by Author. Published by Universitas Pendidikan Ganesha.

\section{INTRODUCTION}

Indonesia has significant challenges in handling Covid-19. The Covid-19 pandemic forces learning activities to be carried out online (Laksana, 2020; Storch et al., 2021). This is to prevent the spread of the Covid19 virus. The Covid-19 pandemic has forced social distancing policies, or in Indonesia, it is better introduced as physical distancing to minimize the spread of Covid-19 (Fitriyani et al., 2020; Sari et al., 2020). This causes teachers to be required to master technology to be able to design online learning (Ramkissoon et al., 2020; Tondeur et al., 2019). The online learning system is a learning system without face-to-face directly between students and teachers but is carried out online via the internet (Kurtz et al., 2014; Zhang et al., 2020). In online learning, teachers must ensure that learning activities continue to study well, even though students are at home. This is what causes teachers to be required to design learning models, media, or teaching materials that can facilitate students when learning online (Awaludin et al., 2020; Silalahi, 2020). Online learning systems require personal devices such as computers, laptops, or mobile phones connected to the internet network. Teachers can carry out learning activities via telegram, WhatsApp, ZOOM, and Google meet as learning applications (Mpungose, 2021; Suhery et al., 2020). Thus, the teacher can ensure that students take part in learning simultaneously, even though in different places.

The problem that occurs today is that many teachers have difficulty designing online learning (Aji, 2020; Mansyur, 2020; Windhiyana, 2020). This problem is also found in high school. Based on the results of observations 
and interviews conducted at SMA Negeri 1 Mengwi, it was found that teachers still had difficulties in preparing the EFL lesson plans. In addition, students find it challenging to learn EFL through Google Classroom. Generally, a professional teacher should have a plan before teaching. RPP is a guideline for the implementation of learning. Teachers usually develop better lesson plans to get a better learning implementation process. Before the Covid-19 pandemic, the RPP was organized by the English Subject Teacher Consultation (MGMP) or the EFL Teacher's Coordinator Group. EFL teachers use lesson plans. EFL uses the compromised lesson plans in face-to-face or onesided interactions at SMAN 1 Mengwi. During the Covid-19 pandemic, the Ministry of National Education and Culture replaced the EFL learning process with an online learning platform. The policy about online learning brings new challenges and difficulties through Google Classroom to both students and teachers, especially in SMA Negeri 1 Mengwi.

Generally, EFL teachers faced difficulties in preparing lesson plans through Google Classroom. Preparing lesson plans through Google Classroom requires not only the teacher's ability, but also the skills to characterize EFL as an easy-to-learn, integrating with lots of applications and websites, moving freely from one thing to another easily, and making use of optimally G Suit document. EFL teachers difficulties faced in preparing lesson plans through Google Classroom in Senior High School 1 Mengwi was related to ability in 1) relating learning indicators with basic competency, 2) relating learning materials, learning indicators with basic competency, 3) relating learning methods or techniques with learning materials, learning indicators with basic competency, 4) relating learning procedures or steps in EFL, 5) relating evaluation and learning indicators, 6) relating evaluation instruments and techniques with learning indicators, 7) relating Information Technology to EFL, and 8) using Information Technology, especially Google Classroom in EFL.

The students might be confronted with facilitative and technical problems in 1) possessing a desktop/laptop/mobile phone, 2) logging to Online Learning Platform without difficulty or without others' assistance, 3) using account to $\log$ in, 4) selecting account to $\log$ in, 5) $\log$ in without difficulty, 6) joining the online class, 7) switching between accounts, 8) connecting without troubles, 9) posting comments through Google Classroom,10) cancelling comments after posting through Google Classroom, 11) finding problems with e-mail, either in sending or receiving e-mail, 12) turning in assignments through Google Classroom, 13) getting enclosures or handouts from teachers, 14) using wrong language, 15) understanding EFL through Google Classroom, 16) liking EFL through Google Classroom, 17) being motivated in EFL through Google Classroom, 18) perceiving positively EFL through Google Classroom, 19) perceiving EFL flexibility through Google Classroom , and 20) perceiving EFL positively with learning materials, examples or illustrations.

Online learning is essential. Learning must continue to run smoothly to achieve learning objectives (Lim et al., 2021; Tang et al., 2021). Teachers can design and design online learning that is light and effective by utilizing appropriate learning devices or media and by the material being taught. This causes students to be easy to follow online learning. Although learning with courage will have wider opportunities to explore the material to be taught, the teacher must choose and limit the scope of the material and the application that is suitable for the material and learning methods used. Previous research findings stated that online learning is essential to be applied by teachers (Dewi, 2020; Putria et al., 2020; Sutarto, 2017). Other research findings also state that to maintain the quality of human resources, online learning must continue until the world improves (Mpungose, 2021; Shah et al., 2020; Yulia, 2020). This indicates that teachers must be able to design online learning to facilitate student learning. The purpose of this study is to analyze the abilities and difficulties of teachers in preparing lesson plans and the difficulties of students in learning English as a foreign language (EFL) through Google Classroom during the Covid-19 pandemic at SMA Negeri 1 Mengwi.

\section{METHOD}

The design that used in the present research was the Embedded Mix Method design. (Ellis,1997; Hopkins,2008; Creswell et al., 2000). The objective was to measure and identify EFL teacher's ability in preparing and difficulties found, as well as the students' difficulties in learning EFL through Google Classroom in SMA Negeri 1 Mengwi (Alwright et. al,1991; Hopkins,2008). The teacher's ability in preparing lesson plans for EFL through Google Classroom was measured and described quantitatively. Whilst, the teacher's and students' difficulties were qualitatively described and analyzed. The teacher's ability in preparing lesson plans for EFL through Google Classroom was rated in terms of $1=$ very poor; $2=$ poor; $3=$ good; 4 = very well. Teacher's difficulties in preparing lesson plans for EFL through Google Classroom were gathered in two steps. First, they had to rate their ability on each aspect of lesson plans' preparation as objectively as they experienced. Second, they had to confirm the rating to the difficult aspects using a rubric.

There was an EFL teacher recruited for the research subject. This teacher has taught for about 32 years. In the academic year 2020/2021, the teacher teaches twelve classes in $10^{\text {th }}$ grade. The students were also recruited from the two classes for research subjects. However, 55 students returned the questionnaire. They consisted of 19 male students and 36 female students. Teacher's ability in preparing lesson plans through Google Classroom 
targeted eight indicators, are the relevance of learning indicators with basic competency, the relevance of learning materials, learning indicators with basic competency, the relevance of learning methods, the relevance of learning procedures or steps, relevance of evaluation and learning indicators, relevance of evaluation instruments and techniques, relevance of Information Technology. Teacher's difficulties are also concerned with eight indicators as the teacher's ability. They are the relevance of learning indicators with basic competency, the relevance of learning materials, learning indicators with basic competency, the relevance of learning methods, the relevance of learning procedures or steps, relevance of evaluation and learning indicators, relevance of evaluation instruments and techniques, relevance of Information Technology.

There was three research instrument to collect the data. The first instrument was a rating scale. A rating scale was used to collect data on the ability of EFL teaching staff in preparing plans for a lesson through Google Classroom. This instrument was adopted and translated from "Instrumen Penilaian Persiapan Pembelajaran Undiksha 2020". The second instrument was a questionnaire. A questionnaire was used to collect data on difficulties found by EFL teachers in preparing EFL through Google Classroom in The Senior High School. The questionnaire of teacher's difficulties in preparing lesson plans for EFL through Google Classroom contained eight items. First, EFL teachers had to rate their ability in preparing lesson plans for EFL through Google Classroom as objectively as they experienced. Second, they had to specify the difficulties following the rating based on the rubric. The third instrument was a questionnaire. A questionnaire was used to collect data on difficulties found by EFL students in learning EFL through Google Classroom in The Senior High School. The questionnaire contained 20 items.

\section{RESULT AND DISCUSSION}

\section{Result}

Preparing lesson plans for EFL through Google Classroom was measured by eight aspects, namely 1) relation of learning indicators with basic competency, 2) relation of learning materials, learning indicators with basic competency, 3) relation learning methods or techniques with learning materials, learning indicators with basic competency, 4) relation of learning procedures or steps in EFL, 5) relation of evaluation and learning indicators, 6) relation of evaluation instruments and techniques with learning indicators, 7) relation of Information Technology to EFL, and 8) using Information Technology, especially Online Learning platform in EFL. The lesson plans prepared by the teacher were evaluated by two independent evaluators to ensure reliability and validity of measurement.

Based on the results of data analysis obtained, the teacher's ability mean score in preparing lesson plans for EFL through Google Classroom $=67.50$. When the teacher's ability mean scores are ordered, the teacher's ability mean score $=68.40$ is the highest, followed by the teacher's ability mean score $=67.50$ and 66.60 . However, when the teacher's ability mean scores were categorized, they are all in the moderate category (mean \pm 1 standard deviation or $67.50 \pm 1.27$ ). The variability of scores among EFL teachers is not very large (variance statistic $=$ 1.62). The range statistic $=1.80$ between the minimum and maximum scores.

When analyzed per aspect, the teacher's ability is found less able in selecting learning methods or techniques with learning materials for basic competencies 1,2, and 4. The teacher's ability was less able in selecting learning procedures for basic competencies 1,2, and 5. The teacher's ability was less able in relating the evaluation with learning indicators for basic competency 4 . The teacher's ability was found less able in relating the evaluation instruments and techniques for basic competencies 1 and 4. In conclusion, the EFL teacher was less able in selecting learning methods or techniques based on the teacher's ability, learning materials, students' characteristics, and basic competency as well as learning indicators. The EFL teacher was less able in selecting learning procedures or steps. The EFL teacher also was less able in conducting the learning evaluation which is objective and consistent with efficiency in terms of time, cost, and energy. The EFL teacher was less able in selecting the evaluation instruments and techniques relate to learning indicators and evaluate the learning process and outcome.

In preparing lesson plans for EFL through Google Classroom, the EFL teacher found difficulties. The teacher was asked to rate his ability in preparing lesson plans as objectively as possible as they experienced. After self-rating, he described sources or descriptions of difficulty in each aspect of lesson plans. The teacher found difficulty in aspect 3 especially in selecting learning methods or techniques based on students' characteristics and basic competency as well as learning indicators; in aspect 4 especially in selecting the steps which are continued with the association and completed with communication; in aspect 5 especially in conducting learning evaluation containing aspects of objectivity and consistent with efficiency; in aspect 6 especially in selecting the learning evaluation relate to learning indicators and evaluate learning process and outcome, in aspect 7 especially in selecting the learning media.

Students also found difficulty in learning EFL through Google Classroom in SMA Negeri 1 Mengwi. Their difficulties were probed in twenty items. In general, the items asked them to disclose some facilitative and 
technical problems or difficulties in learning EFL through Google Classroom. Students found difficulties in 1) connection, 2) turning assignment through google classroom, 3) understanding EFL through Google Classroom, 4) disliking EFL through Google Classroom, 5) being demotivated in learning EFL through Google Classroom, 6) being negatively perceived in learning EFL through Google Classroom, and 7) perceiving positively to provide them with rich with learning materials, plenty of examples, or varied illustrations. In lesson plan one, especially about introduction, the students mostly found difficulties in connection (58.19\%), turning assignments through google classroom (12.73\%), understanding the EFL through google classroom (54.55\%), disliking EFL through Google Classroom (5.46\%), being demotivated in learning EFL through google classroom (52.73\%), being negatively perceived in learning EFL through Google Classroom (56.37\%), perceiving positively to provide them with rich with learning materials, plenty of examples, or varied illustrations $(50.91 \%)$.

In lesson plan two, especially about making a script of holiday plan, the students mostly found difficulties in connection $(52.73 \%)$, turning assignments through google classroom (21.82\%), understanding the EFL through google classroom (50.91\%), disliking EFL through Google Classroom (52.73\%), being demotivated in learning EFL through google classroom (52.73\%), being negatively perceived in learning EFL through Google Classroom $(52.73 \%)$, perceiving positively to provide them with rich with learning materials, plenty of examples, or varied illustrations $(21.82 \%)$.

In lesson plan three, especially about congratulating expressions, the students found difficulties in connection (25.46\%), turning assignments through google classroom (54.55\%), understanding the EFL through google classroom (12.73\%), disliking EFL through Google Classroom (21.82\%), being demotivated in learning EFL through google classroom (25.46\%), being negatively perceived in learning EFL through Google Classroom $(21.82 \%)$, perceiving positively to provide them with rich with learning materials, plenty of examples, or varied illustrations $(49.10 \%)$. It means that not too many students found difficulties in this skill.

In lesson plan four, especially about the announcement, the students found difficulties in connection (18.19\%), turning assignments through google classroom $(52.73 \%)$, understanding the EFL through google classroom (58.19\%), disliking EFL through Google Classroom (56.37\%), being demotivated in learning EFL through google classroom (21.82\%), being negatively perceived in learning EFL through Google Classroom $(10.91 \%)$, perceiving positively to provide them with rich with learning materials, plenty of examples, or varied illustrations $(49.10 \%)$.

In lesson plan five, especially about descriptive text, the students found difficulties in connection $(10.91 \%)$, turning assignments through google classroom (5.46\%), understanding the EFL through google classroom (10.91\%), disliking EFL through Google Classroom (25.46\%), being demotivated in learning EFL through google classroom $(12.73 \%)$, being negatively perceived in learning EFL through Google Classroom $(21.82 \%)$, perceiving positively to provide them with rich with learning materials, plenty of examples, or varied illustrations (12.73\%). It means that not too many students found difficulties in this lesson plan. In conclusion, the EFL students found 7 aspects of EFL through the Google Classroom learning paradigm. The most difficulties found in lesson plans 1,2 , and 3 .

\section{Discussion}

The research finding shows that EFL teacher was less able to prepare lesson plans for EFL through Google Classroom in SMA Negeri 1 Mengwi. The teacher was less able in aspects 3, 4, 5, and 6. More specifically, the teacher was less able to 1) selecting learning methods or techniques suited to students' characteristics, 2) selecting learning methods or techniques matched with basic competency as well as learning indicators, 3) determining learning steps continued to association, 4) determining learning steps completed with communication, 5) conducting learning evaluation which is objectivity, 6) conducting learning evaluation which is consistent with efficiency in terms of time, cost, and energy, 7) selecting the evaluation instruments and technique relate to learning indicators, 8) selecting the evaluation instruments and technique which is evaluate learning process and outcome.

Adaptability struggle refers to an ability to switch from the traditional classroom and face-to-face instructor training to computer-based learning or on-line based learning (Darmaji et al., 2019; Kazua \& Demirkol, 2014). The teacher and students find something new with these learning circumstances. In technical issues, many teachers and students are not provided with the strong internet connection that online courses require, and thus fail to catch up with their online learning (Hogan \& Devi, 2019; Yustina et al., 2020). Besides that, the EFL teacher and students are not computer literate. Not all of them can manage computers well and operate basic computer programs such as Microsoft Word, Microsoft power points, as well as Google Classroom, therefore they are not able to handle their files (Adedoyin \& Soykan, 2020; Albashtawi \& Al Bataineh, 2020). Time management is a difficult task for EFL teachers and students. Online learning requires a lot of time and intensive work.

The research finding also showed that the teacher's difficulties in preparing lesson plans are divided into two major scopes, they are in academic area and technology area (Ja'ashan, 2020; Logan et al., 2021). The teacher found difficulty in aspect 3, especially in selecting learning methods or techniques based on students' 
characteristics and basic competency as well as learning indicators. It was because the teacher still do not understand the characteristics of his students. Every child has different characteristics (Duman, 2010; Lwande et al., 2021). Learning is carried out by paying attention to the differences in characteristics that an individual has (Mahasneh et al., 2021; Rasheed \& Wahid, 2021).

The other teacher's difficulty found in aspect 4, especially in selecting the steps which are continued with the association and completed with communication. It was because the step of associating and communicating was not applied well in the learning process. Communicating is also known as collaborative learning (Pratamawaty et al., 2019; Suharyadi, 2013). The limitation of time and distance made the EFL teacher consider collaborative learning. But, over time, then the teacher could apply the online learning platforms efficiently, they still found numerous issues such as insufficient suitable materials, learner' low attention, and the decreasing of students' motivation in online learning (Khatoony \& Nezhadmehr, 2020; Sert \& Boynueğri, 2017).

The difficulties found by students related to technology, connection, and academic aspects (Ja'ashan, 2020; Utami et al., 2018). From 20 items in the questionnaire, the difficulties of students were found in seven aspects. They are difficulties in 1) connection, 2) turning assignments through Google Classroom, 3) understanding EFL through Google Classroom learning platform, 4) disliking EFL through Google Classroom learning platform, 5) being demotivated in learning EFL through Google Classroom learning platform, 6) being negatively perceived in learning EFL through Google Classroom platform, and 7) perceiving positively to provide them with rich with learning materials, plenty of examples, or varied illustrations. The students' difficulties in connection are mostly found in lesson plans 1,2, and 4. The first lesson plan was about the introduction. The second lesson plan was about a desire to do something. The fourth lesson plan was about the announcement.

Slow internet connection was one of the difficulties faced by the students (Octaberlina \& Muslimin, 2020; Windhiyana, 2020). It was about 32 students who got into trouble in connection. It was because the students did not commonly use online learning platforms. From the first lesson plan to the last lesson plan, the number of students that found difficulties in connection was decreasing. It happened because not all of them have a strong internet connection and because of the weather. Online learning can be applied in long-distance learning, where internet resource is stable (Widiyono, 2020).

The students stated that they commonly needed grammar which closed to the topics during online learning (Bradley, 2020; Nartiningrum \& Nugroho, 2020). The students were being demotivated in learning EFL through Google Classroom mostly in the first and second lesson plans. The reasons were 1) they were difficult to practice their English directly, and 2) they were easy to find out the material and easy to forget it because they can not practice it directly. The students were being negatively perceived to provide them with rich learning materials, plenty of examples, or varied illustrations mostly found in the first lesson plan about an introduction. The reasons were 1) they were anxious about the material they got would be wrong, and 2) they were difficult to understand the material or examples they got by themselves.

\section{CONCLUSION}

EFL teacher was difficult in selecting learning methods or techniques based on students' characteristics and basic competency as well as learning indicators; selecting the steps which are continued with the association and completed with communication; conducting learning evaluation containing aspects of objectivity and consistent with efficiency; selecting the learning evaluation relate to learning indicators and evaluate learning process and outcome, selecting the learning media. EFL students were also difficult in connection, turning assignments through Google Classroom, understanding EFL through Google Classroom learning platform, disliking EFL through Google Classroom learning platform, being demotivated in learning EFL through Google Classroom learning platform, being negatively perceived in learning EFL through Google Classroom platform, and perceiving positively to provide them with rich with learning materials, plenty of examples, or varied illustrations.

\section{REFERENCES}

Adedoyin, O. B., \& Soykan, E. (2020). Covid-19 pandemic and online learning: the challenges and opportunities. In Interactive Learning Environments. https://doi.org/10.1080/10494820.2020.1813180

Aji, R. H. S. (2020). Dampak Covid-19 pada Pendidikan di Indonesia: Sekolah, Keterampilan, dan Proses Pembelajaran $\square$ Dampak Covid-19 pada Pendidikan di Indonesia: Sekolah, Keterampilan, dan Proses Pembelajaran. Jurnal Sosial \& Budaya Syar-I, 5(1), 395-402. https://doi.org/10.15408/sjsbs.v7i5.15314

Albashtawi, A. H., \& Al Bataineh, K. B. (2020). The effectiveness of google classroom among EFL students in Jordan: An innovative teaching and learning online platform. International Journal of Emerging Technologies in Learning, 15(11), 78-88. https://doi.org/10.3991/IJET.V15I11.12865 
Awaludin, Wibawa, \& Winarsih. (2020). Integral Calculus Learning Using Problem Based Learning Model Assisted by Hypermedia-Based E-Book. Jurnal Pendidikan Indonesia, 9(2). https://doi.org/10.23887/jpiundiksha.v9i2.23106

Bradley, V. M. (2020). Learning Management System (LMS) Use with Online Instruction. International Journal of Technology in Education, 4(1), 68. https://doi.org/10.46328/ijte.36

Creswell, J. W., Miller, D. L., Creswell, J. W., \& Miller, D. L. (2000). in Qualitative Inquiry. 5841 (March), 37 41. https://doi.org/10.1207/s15430421tip3903

Darmaji, Kurniawan, D. A., Astalini, Lumbantoruan, A., \& Samosir, S. C. (2019). Mobile learning in higher education for the industrial revolution 4.0: Perception and response of physics practicum. In International Journal of Interactive Mobile Technologies (Vol. 13, Issue 9). https://doi.org/10.3991/ijim.v13i09.10948

Dewi, W. A. F. (2020). Dampak COVID-19 terhadap Implementasi Pembelajaran Daring di Sekolah Dasar. Jurnal Edukatif Ilmu Pendidikan, 2(1). https://doi.org/10.31004/edukatif.v2i1.89

Duman, B. (2010). The Effects of Brain-Based Learning on the Academic Achievement of Students with Different Learning Styles. Educational Sciences: Theory \& Practice, 10(4), 2077-2103.

Fitriyani, Y., Fauzi, I., \& Sari, M. Z. (2020). Motivasi Belajar Mahasiswa Pada Pembelajaran Daring Selama Pandemik Covid-19. Profesi Pendidikan Dasar, 7(1), 121-132. https://doi.org/10.23917/ppd.v7i1.10973

Hogan, R., \& Devi, M. (2019). Asynchronous pedagogy to improve online student success. International Journal of Online Pedagogy and Course Design, 9(3), 61-77. https://doi.org/10.4018/IJOPCD.2019070105

Ja' ashan, M. (2020). The Challenges and Prospects of Using E-learning among EFL Students in Bisha University. Arab World English Journal, 11(1), 124-137. https://doi.org/10.24093/awej/vol11no1.11

Kazua, I. Y., \& Demirkol, M. (2014). Effect of Blended Learning Environment Model on High School Students' Academic Achievement. Turkish Online Journal of Educational Technology-TOJET, 13(1), 78-87.

Khatoony, S., \& Nezhadmehr, M. (2020). EFL teachers' challenges in integration of technology for online classrooms during Coronavirus (COVID-19) pandemic in Iran. AJELP: Asian Journal of English Language and Pedagogy, 8(2), 1-16.

Kurtz, G., Tsimerman, A., \& Steiner, O. (2014). The Flipped Classroom Answer to Future Learning? European Journal of Open, Distance and E-Learning, 17(2). https://doi.org/10.2478/eurodl-2014-0027

Laksana, D. N. L. (2020). Implementation of Online Learning in The Pandemic Covid-19: Student Perception in Areas with Minimum Internet Access. Journal of Education Technology, 4(4), 509-509. https://doi.org/10.23887/jet.v4i4.29314

Lim, M. T. C., Ramamurthy, M. B., Aishworiya, R., Rajgor, D. D., Tran, A. P., Hiriyur, P., Kunaseelan, S., Jabri, M., \& Goh, D. Y. T. (2021). School closure during the coronavirus disease 2019 (COVID-19) pandemic Impact on children's sleep. Sleep Medicine, 78(January 2020), 108-114. https://doi.org/10.1016/j.sleep.2020.12.025

Logan, R. M., Johnson, C. E., \& Worsham, J. W. (2021). Development of an E-learning Module to Facilitate Student Learning and Outcomes. Teaching and Learning in Nursing, 16(2), 139-142. https://doi.org/10.1016/j.teln.2020.10.007

Lwande, C., Muchemi, L., \& Oboko, R. (2021). Identifying learning styles and cognitive traits in a learning management system. Heliyon, 7(8). https://doi.org/10.1016/j.heliyon.2021.e07701

Mahasneh, D., Shoqirat, N., Singh, C., \& Hawks, M. (2021). "From the classroom to Dr. YouTube": nursing students' experiences of learning and teaching styles in Jordan. Teaching and Learning in Nursing, 16(1). https://doi.org/10.1016/j.teln.2020.09.008

Mansyur, A. R. (2020). Dampak COVID-19 Terhadap Dinamika Pembelajaran Di Indonesia. Education and Learning Journal, 1(2), 113. https://doi.org/10.33096/eljour.v1i2.55

Mpungose, C. B. (2021). Lecturers' reflections on the use of Zoom video conferencing technology for e-learning at a South African university in the context of coronavirus. African Identities. https://doi.org/10.1080/14725843.2021.1902268

Nartiningrum, N., \& Nugroho, A. (2020). Online Learning amidst Global Pandemic : EFL Students ' Challenges, Suggestions, and Needed Materials. Academic Journal of English Language and Education, 4(2), 115-140. https://doi.org/10.29240/ef.v4i2.1494

Octaberlina, L. R., \& Muslimin, A. I. (2020). EFL Students Perspective towards Online Learning Barriers and Alternatives Using Moodle / Google Classroom during COVID-19 Pandemic. International Journal of Higher Education, 9(6), 1-9. https://doi.org/10.5430/ijhe.v9n6p1

Pratamawaty, Dewi, \& Trulline. (2019). Model strategi komunikasi politik sosialisasi kebijakan Masyarakat Ekonomi ASEAN di Bandung Barat B. Jurnal Kajian Komunikasi, 7(2). https://doi.org/10.24198/jkk.v7i2.23362

Putria, H., Maula, L. H., \& Uswatun, D. A. (2020). Analisis Proses Pembelajaran dalam Jaringan (DARING) Masa Pandemi Covid- 19 Pada Guru Sekolah Dasar. Jurnal Basicedu, 4(4), 861-872. https://doi.org/10.31004/basicedu.v4i4.460 
Ramkissoon, P., Belle, L. J., \& Bhurosy, T. (2020). Perceptions and experiences of students on the use of interactive online learning technologies in Mauritius. International Journal of Evaluation and Research in Education. https://doi.org/10.11591/ijere.v9i4.20692

Rasheed, F., \& Wahid, A. (2021). Learning style detection in E-learning systems using machine learning techniques. Expert Systems with Applications, 174. https://doi.org/10.1016/j.eswa.2021.114774

Sari, I., Sinaga, P., Hernani, \& Solfarina. (2020). Chemistry Learning via Distance Learning during the Covid-19 Pandemic. TADRIS (Journal of Education and Teacher Training), 5(1). https://doi.org/10.24042/tadris.v5i1.6346

Sert, N., \& Boynueğri, E. (2017). Digital technology use by the students and English teachers and self-directed language learning. World Journal on Educational Technology: Current Issues, 9(1), 24. https://doi.org/10.18844/wjet.v9i1.993

Shah, K., Arfan, M., Mahariq, I., Ahmadian, A., Salahshour, S., \& Ferrara, M. (2020). Fractal-Fractional Mathematical Model Addressing the Situation of Corona Virus in Pakistan. Results in Physics, 19, 103560. https://doi.org/10.1016/j.rinp.2020.103560

Silalahi, M. V. (2020). Development of E-Modules Based on Exe-Learning on Topics of Reaction Rate Against Student Learning Outcomes Mechanical Engineering. International Journal of Education and Curriculum Application, 3(2), 114-120. https://doi.org/10.31764/ijeca.v3i2.2672

Storch, E. A., Sheu, J. C., \& Guzick, A. G. et al. (2021). Impact of the COVID-19 pandemic on exposure and response prevention outcomes in adults and youth with obsessive-compulsive disorder. Psychiatry Research, 295(October 2020), 113597. https://doi.org/10.1016/j.psychres.2020.113597

Suharyadi. (2013). Exploring scientific approach in English language teaching. Seminar Nasional Exchange of Experiences: Teacher Quality Improvement Program (TQIP), January 1348-1355.

Suhery, Putra, \& Jasmalinda. (2020). Sosialisasi Penggunaan Aplikasi Zoom Meeting dan Google Classroom Pada Guru Di SDN 17 Mata Air Padang Selatan. Jurnal Inovasi Penelitian, 1(3), 129-132. https://stp-mataram.ejournal.id/JIP

Sutarto, S. (2017). Dampak Pengiring Pembelajaran Pendekatan Saintifik Untuk Mengembangan Sikap Spiritual Dan Sosial Siswa. Jurnal Cakrawala Pendidikan, 36(1), 44-56. https://doi.org/10.21831/cp.v36i1.12792

Tang, Y. M., Chen, P. C., Law, K. M. Y., Wu, C. H., Lau, Y., Guan, J., He, D., \& Ho, G. T. S. (2021). Comparative analysis of Student's live online learning readiness during the coronavirus (COVID-19) pandemic in the higher education sector. Computers \& Education, $168, \quad 104211$. https://doi.org/10.1016/j.compedu.2021.104211

Tondeur, J., Scherer, R., Baran, E., Siddiq, F., Valtonen, T., \& Sointu, E. (2019). Teacher educators as gatekeepers: Preparing the next generation of teachers for technology integration in education. British Journal of Educational Technology, 50(3), 1189-1209. https://doi.org/10.1111/bjet.12748

Utami, T. N., Jatmiko, A., \& Suherman, S. (2018). Pengembangan Modul Matematika dengan Pendekatan Science, Technology, Engineering, And Mathematics (STEM) pada Materi Segiempat. Desimal: Jurnal Matematika, 1(2), 165. https://doi.org/10.24042/djm.v1i2.2388

Widiyono, A. (2020). Efektifitas Perkuliahan Daring (Online) pada Mahasiswa PGSD di Saat Pandemi Covid 19. Jurnal Pendidikan, 8(2), 169-177. https://doi.org/10.36232/pendidikan.v8i2.458

Windhiyana, E. (2020). Dampak Covid-19 Terhadap Kegiatan Pembelajaran Online Di Perguruan Tinggi Kristen Di Indonesia. Perspektif Ilmu Pendidikan, 34(1), 1-8. https://doi.org/10.21009/pip.341.1

Yulia, H. (2020). Online Learning to Prevent the Spread of Pandemic Corona Virus in Indonesia. ETERNAL (English Teaching Journal), 11(1). https://doi.org/10.26877/eternal.v11i1.6068

Yustina, Syafii, W., \& Vebrianto, R. (2020). The effects of blended learning and project-based learning on preservice biology teachers' creative thinking skills through online learning in the COVID-19 pandemic. Jurnal Pendidikan IPA Indonesia, 9(3), 408-420. https://doi.org/10.15294/jpii.v9i3.24706

Zhang, Y., Ghandour, A., \& Shestak, V. (2020). Using Learning Analytics to Predict Students Performance in Moodle LMS. International Journal of Emerging Technologies in Learning. https://doi.org/10.3991/ijet.v15i20.15915 